\title{
Respiratory Changes in Patients with Stroke
}

\section{Alterações Respiratórias nos Pacientes com Acidente Vascular}

\author{
Rita Ocko ${ }^{1} \&$ Maria do Céu Costa ${ }^{1,2}$ \\ ${ }^{1}$ Escola de Ciências e Tecnologias da Saúde, Universidade Lusófona, Campo Grande 376, 1749-024 Lisboa \\ ${ }^{2}$ CBIOS - Research Center for Health Science and Technologies, Universidade Lusófona \& ERISA -Escola Superior de \\ Saúde Ribeiro Sanches, Campo Grande, 376, 1749-024, Lisboa, Portugal
}

Email: rita.ocko@gmail.com

\begin{abstract}
This study aimed to review published literature concerning the major changes that occur in the respiratory system after stroke, and also the impact of respiratory muscle training in these patients. The literature search was conducted through electronic databases (PubMed, SciELO and Pedro) in Portuguese and English languages on themes related to changes in the respiratory system and methods of assessment and rehabilitation of respiratory muscle strength in individuals affected by stroke. There is scientific evidence that individuals affected by stroke may show decreased inspiratory and expiratory muscle strength. Studies suggest that respiratory muscle training through threshold load can bring benefits by improving respiratory function and respiratory muscle strength. However, more studies should be conducted to deepen the knowledge about the benefits and long-term effects of pulmonary rehabilitation in patients with stroke.
\end{abstract}

Keywords: Stroke, Respiratory Muscle Strength, Maximum Respiratory Pressure and Respiratory Muscle Training.

\section{Resumo}

O objetivo deste estudo foi realizar uma revisão de literatura sobre as principais alterações que ocorrem no sistema respiratório após o Acidente Vascular Cerebral (AVC) e também sobre os efeitos de treino muscular respiratório nestes pacientes. A metodologia adotada foi a pesquisa de artigos através das bases de dados electrónicas (Pubmed, Scielo e Pedro) em língua portuguesa e inglesa relacionando os temas: alterações do sistema respiratório e métodos de avaliação e reabilitação da força muscular respiratória em indivíduos acometidos pelo AVC. Existe evidência científica de que indivíduos acometidos pelo AVC podem apresentar diminuição da força muscular inspiratória e expiratória. Estudos sugerem que o treino muscular respiratório, através de carga limiar, pode trazer benefícios quanto a melhora da função respiratória e da força dos músculos respiratórios. Porém, mais estudos devem ser realizados para o aprofundamento do conhecimento sobre os benefícios e efeitos a longo prazo da reabilitação respiratória em pacientes com AVC.

Palavras-chave: Acidente Vascular Cerebral, Força Muscular Respiratória, Pressão Respiratória Máxima e Treino Muscular Respiratório. 


\section{Introduction}

Globally, stroke is a major cause of mortality and disability ${ }^{(1,2)}$ worldwide. The World Health Organization defines stroke as rapidly developing clinical signs of focal (or global) disturbance of cerebral function, with symptoms lasting for more than 24 hours or leading to death with no apparent other cause than vascular origin (3). Consequences depend on the location of the lesion, size, and the amount of collateral blood flow. The most common physical change is hemiplegia or hemiparesis, corresponding to motor impairment characterized by total or partial loss of movement in the hemisphere contralateral to the brain lesion ${ }^{(4)}$. It can also be accompanied by sensory changes, including cognitive, visual, perceptual, and language ${ }^{(5)}$, as well as changes in respiratory muscles, the latter being important and yet little discussed in the literature. Recent studies have reported changes in respiratory muscle strength in individuals affected by stroke in the acute and chronic disease when compared to healthy subjects ${ }^{(5,6,7,8)}$. Respiratory muscle strength can be evaluated through nonvolitional tests that are performed through electrical or magnetic stimulation of the phrenic nerve. These evaluations are usually performed in specific pulmonary function laboratories ${ }^{(9)}$. Alternatively, volitional tests may be conducted that require the understanding and cooperation of the individual for the correct execution of the test. These might be achieved invasively by placing a catheter in the medial region of the esophagus or stomach for measurement of transdiaphragmatic pressure, or noninvasively, by means of an analog or digital manometer (mouth pressure meter) which assesses maximal inspiratory and expiratory pressures ${ }^{(10,11)}$.

Respiratory assessment in individuals with stroke is crucial during the neurological rehabilitation process, but, often, little attention is given to it in clinical practice, possibly because these individuals generally do not have a history of pulmonary disease or because obvious signs and symptoms of respiratory dysfunction are simply absent ${ }^{(6,7,8,12)}$. The aim of this study was to review the published literature concerning the major changes occurring in the respiratory system after stroke, with a focus on respiratory muscles and on the impact of respiratory muscle training programs in these patients.

\section{Materials and Methods}

The research literature search was conducted through electronic databases (PubMed, SciELO and Pedro) in

\section{Introdução}

O Acidente Vascular Cerebral é mundialmente uma das principais causas de mortalidade e incapacidade funcional $^{(1,2)}$.

A Organização Mundial de Saúde define o AVC como o desenvolvimento rápido de sinais clínicos de distúrbios focais (ou globais) da função cerebral, com sintomas que perduram durante um tempo maior que 24 horas ou conduzem à morte, sem outra causa aparente que a origem vascular ${ }^{(3)}$.

As sequelas dependem da localização, do tamanho da lesão e da quantidade de fluxo sanguíneo colateral. A alteração física mais comum é a hemiplegia ou hemiparesia, correspondente à deficiência motora caracterizada por perda total ou parcial do movimento no hemicorpo contralateral à lesão encefálica ${ }^{(4)}$. Também pode ser acompanhada por alterações sensitivas, cognitivas, visuais, perceptivas, da linguagem ${ }^{(5)}$ e dos músculos respiratórios, sendo este último importante e ainda pouco discutido na literatura científica.

Estudos recentes evidenciaram alterações da força muscular respiratória em indivíduos acometidos pelo AVC tanto na fase aguda como crónica da doença comparativamente a indivíduos saudáveis ${ }^{(5,6,7,8)}$.

A força muscular respiratória pode ser avaliada através de testes não volitivos que são realizados através de estimulação elétrica ou magnética do nervo frénico e são geralmente realizados em laboratórios específicos de função pulmonar ${ }^{(9)}$. A avaliação podem também ser efetuada através de testes volitivos que necessitam compreensão e colaboração do indivíduo para a correta execução do teste. E que pode ser realizado de duas maneiras: forma invasiva, com a colocação de um cateter na região medial do esófago ou do estômago para a medida da pressão transdiafragmática e forma não invasiva, por meio de um manómetro (analógico ou digital) que avalia as pressões inspiratória e expiratória máximas ${ }^{(10,11)}$.

A avaliação respiratória em indivíduos com AVC em processo de reabilitação neurológica é de fundamental importância, mas comumente na prática clínica pouca atenção é dada à mesma, possivelmente pelo facto dos indivíduos não apresentarem histórico de doença pulmonar prévia ou sinais e sintomas óbvios de disfunção respiratória ${ }^{(6,7,8,12)}$.

O objetivo deste estudo foi realizar uma revisão de literatura sobre as principais alterações que ocorrem no sistema respiratório após o AVC, com enfoque na musculatura respiratória e também sobre os efeitos do programa de treino muscular respiratório nestes pacientes.

\section{Materiais e Métodos}

A pesquisa de artigos foi realizada através das bases de dados eletrónicas (Pubmed, Scielo e Pedro) em língua 
Portuguese and English languages, with a focus toward research regarding changes in the respiratory system in patients with stroke and assessment - rehabilitation methods of respiratory muscle strength in these patients. Specific keywords, such as Stroke, Respiratory Muscle Strength, Maximal Respiratory Pressures and Respiratory Muscle Training and equivalents were used for the search. The article search was set from January 2012 to July 2013. Several original articles and two systematic reviews were selected, analyzed and reflexively synthetized in order to gather consistent information.

\section{Major Changes of the Respiratory System After Stroke}

Stroke can affect the respiratory system function by causing abnormal breathing (5), affecting pulmonary function or respiratory muscle activity patterns $(5,6,8)$. The changes that occur in the respiratory system after stroke depend on the extent and location of the brain injury and may result from disorders of the central rhythm generation, disruption of pathways that carry impulses to the respiratory centers, or bulbar weakness ${ }^{(13)}$. One major abnormal breathing pattern found in patients affected by stroke is the Cheyne Stokes rhythm. However, other patterns can be observed, such as central neurogenic hyperventilation, apneustic breathing, ataxic pattern, sleep apnea ${ }^{(13,14)}$ and nocturnal hypoxemia ${ }^{(15)}$. Studies have shown that in addition to the breathing pattern changes, patients affected by stroke may also show decreased ventilatory function ${ }^{(16,17)}$ and respiratory muscle strength ${ }^{(5,8,18)}$.

Changes related to respiratory function which were described in the literature were evaluated by different methods. A study using X-rays published in the late 1960's reported that individuals with stroke had decreased chest movement on the affected side, indicating a reduction of respiratory muscle activity independent of age, gender, ethnicity, and time since lesion onset ${ }^{(19)}$. Decades later, and by more modern methods, studies have shown a reduced diaphragmatic excursion in these patients after stroke ${ }^{(20,21)}$.

De Troyer et al. (1981) ${ }^{(20)}$ demonstrated by electromyography a reduction in diaphragmatic activity of the hemiplegic side in acute stroke patients and a decrease in amplitude and action potential of the intercostal muscles in both the hemiplegic and the unaffected sides. The authors concluded that the inspiratory muscles were affected due to a unilateral corticospinal lesion, thus demonstrating a direct relationship with these underactive muscles and hemiplegia. portuguesa e inglesa relacionando as alterações do sistema respiratório em pacientes com Acidente Vascular Cerebral (AVC) e os métodos de avaliação e reabilitação da força muscular respiratória nestes pacientes. Para a busca nas bases de dados, foram utilizadas palavras-chave especificas como Acidente Vascular Cerebral, Força Muscular Respiratória, Pressões Respiratórias Máximas e Treino Muscular Respiratório e seus equivalentes. A seleção dos artigos ocorreu entre janeiro de 2012 e julho de 2013, permitindo a analise de diversos artigos originais e duas revisões sistemáticas. Os textos foram analisados e sintetizados de forma reflexiva a fim de obter informações consistentes.

\section{Principais Alterações do Sistema Respiratório Após AVC}

O AVC pode afetar a função do sistema respiratório em termos de anormalidades no padrão respiratório ${ }^{(5)}$, na função pulmonar e nos músculos respiratórios ${ }^{(5,6,8)}$.

As alterações que ocorrem no sistema respiratório após o AVC dependem do nível e da localização da lesão encefálica, podendo ocorrer distúrbios na geração do ritmo central, interrupção das vias que levam os impulsos aos centros respiratórios ou ainda fraqueza bulbar ${ }^{(13)}$. Um dos principais padrões respiratórios anormais encontrados em pacientes acometidos pelo AVC é o ritmo Cheyne Stokes. Entretanto, outros padrões podem ser observados como: hiperventilação neurogénica central, respiração apnêustica, padrão atáxico, apneia do sono ${ }^{(13,14)}$ e hipoxemia noturna ${ }^{(15)}$.

Estudos já evidenciaram que além das alterações do padrão respiratório, os pacientes acometidos pelo AVC podem apresentar também redução da função ventilatória ${ }^{(16,17)}$ e da força dos músculos respiratórios ${ }^{(5,8,18)}$. As alterações relacionadas com a função respiratória descritas na literatura foram avaliadas através de diferentes métodos. No final da década de 60 , observou-se num estudo através de radiografias que indivíduos com AVC apresentavam diminuição do movimento do tórax do lado afetado, indicando uma redução da ação dos músculos respiratórios independente da idade, sexo, etnia e tempo de início da lesão ${ }^{(19)}$.

Décadas mais tarde e utilizando métodos mais modernos, estudos demostraram que pacientes após serem acometidos pelo AVC apresentam redução da mobilidade diafragmática ${ }^{(20,21)}$.

De Troyer et al., (1981) ${ }^{(20)}$, através da avaliação por eletromiografia, evidenciaram redução na atividade diafragmática do lado hemiplégico, além de uma diminuição da amplitude e potenciais de ação dos músculos intercostais, tanto do lado hemiplégico como do lado não comprometido, em pacientes na fase aguda do AVC. Estes autores concluíram que os músculos inspiratórios estavam afetados devido à lesão unilateral corticoespinal, demostrando assim a existência de uma 
Lanini et al. (2003) ${ }^{(5)}$ evaluated the activity of the respiratory muscles through plethysmography in 8 subjects with acute stroke, along with 9 healthy subjects. It was observed that all stroke patients showed reduced respiratory movement of the affected hemithorax during voluntary hyperventilation when compared with spontaneous breathing.

Khedr et al. (2000) ${ }^{(21)}$ observed by ultrasound a reduction of the diaphragmatic motion in the paralyzed side in $41 \%$ of 34 acute stroke participants evaluated. It was also reported that these hemiplegic patients had a greater degree of hypocapnia and hypoxia, suggesting that hemidiaphragmatic paralysis may contribute to hypoxemia and general dysfunction in these patients.

Some studies have assessed the respiratory muscle weakness severity in patients with stroke by measuring maximum respiratory pressures using a manometer. The use of this device is common in clinical practice to assess respiratory muscle strength and this facilitates diagnosis and prognosis of neuromuscular and pulmonary disorders ${ }^{(22,23)}$. Furthermore, it is regarded as a simple, practical, safe, noninvasive, low cost and highly reliable procedure ${ }^{(9)}$.

Maximal inspiratory pressure $(M I P)$ reflects the overall muscle strength, i.e. evaluates the strength of the muscles involved in inspiration and may not be isolated from the diaphragm, although $70 \%$ of the effort involved in inspiration is the work of that muscle. Maximal expiratory pressure $(M E P)$ reflects the overall expiratory muscle strength, ${ }^{(11,23)}$.

In addition to studying the activity of the respiratory muscles through plethysmography, Lanini et al. (2003) (5) also reviewed the maximal respiratory pressure (MRP). Results have shown that patients with stroke had a significant reduction $(p<0.05)$ of the MIP $(53.43$ $\left.\mathrm{cmH}_{2} \mathrm{O}\right)$ and the $\operatorname{MEP}\left(61.6 \mathrm{cmH}_{2} \mathrm{O}\right)$ values when compared to those of the control group $\left(99.4 \mathrm{cmH}_{2} \mathrm{O} M I P\right.$ and $121.8 \mathrm{cmH}_{2} \mathrm{O} M E P$ ).

Harraf et al. (2008) (24) evaluated respiratory muscle strength in 15 patients with acute stroke compared to 16 healthy subjects matched for age and sex. Results revealed a significant decrease in both maximal inspiratory and expiratory pressures in patients of stroke group (36.7 $\mathrm{cmH}_{2} \mathrm{O} M I P$ and $62.6 \mathrm{cmH}_{2} \mathrm{O} M E P$ ) compared to control group $\left(75.8 \mathrm{cmH}_{2} \mathrm{O} M I P\right.$ and $102.7 \mathrm{cmH}_{2} \mathrm{O}$ $M E P)$.

Ward et al. (2010) ${ }^{(7)}$ also observed a significant reduction $(p<0.05)$ in $M I P\left(38.9 \mathrm{cmH}_{2} \mathrm{O}\right)$ and $M E P$ values $\left(52.5 \mathrm{cmH}_{2} \mathrm{O}\right)$ in 18 adults with acute stroke compared to 19 healthy adults $\left(95.1 \mathrm{cmH}_{2} \mathrm{O} M I P\right.$ and $108.7 \mathrm{~cm}$ $\left.\mathrm{H}_{2} \mathrm{O} M E P\right)$.

The study of Teixeira - Salmela et al. $(2005){ }^{\left({ }^{8}\right)}$ was the first toevaluate the $M I P$ and $M E P$ in adults with chron- relação direta com a hipoatividade destes músculos e a hemiplegia.

Lanini et al. (2003) ${ }^{(5)}$ avaliaram a atividade dos músculos respiratórios através de plestimografia em 8 indivíduos na fase aguda do AVC e 9 saudáveis. Foi observado que todos os pacientes com AVC apresentaram redução do movimento respiratório do hemitórax afetado durante a hiperventilação voluntária quando comparado com a respiração espontânea.

Khedr et al. (2000) ${ }^{(21)}$, através de ultrassonografia observaram redução da mobilidade diafragmática no lado paralisado em $41 \%$ dos 34 participantes avaliados com AVC agudo. Relataram também que estes pacientes com hemiplegia tiveram um maior grau de hipóxia e hipocapnia, sugerindo assim que a paralisia hemidiafragmática pode contribuir para uma hipoxemia e deficiência orgânica prejudicada.

Alguns estudos avaliaram o grau de fraqueza muscular respiratória em pacientes com AVC, através de medidas das pressões respiratória máximas utilizando-se um manómetro. Na prática clínica, é comum a utilização deste dispositivo para a avaliação da força dos músculos respiratórios, pois este auxilia no diagnóstico e prognóstico de desordens neuromusculares e pulmonares ${ }^{(22,23)} \mathrm{e}$, além disso, é considerado um método simples, prático e seguro, não invasivo, de baixo custo e de grande confiabilidade ${ }^{(9)}$.

A pressão inspiratória máxima $\left(P_{\text {imax }}\right)$ reflete a força muscular inspiratória total, ou seja, avalia a força dos músculos que participam da inspiração, não podendo ser isolado o diafragma, embora $70 \%$ do esforço realizado na inspiração corresponda ao trabalho desse músculo. Já a pressão expiratória máxima $\left(P_{\text {emax }}\right)$ reflete a força muscular expiratória avaliando, assim, a força total dos músculos expiratórios ${ }^{(11,23)}$.

Além de estudar a atividade dos músculos respiratórios através de plestimografia, Lanini et al. (2003) $)^{(5)}$ avaliaram também as pressões respiratórias máximas. Os resultados demostraram que os pacientes com AVC apresentaram uma redução significativa $(p<0,05)$ dos valores de $P_{i \max }\left(53,43 \mathrm{cmH}_{2} \mathrm{O}\right)$ e $P_{\text {emax }}(61,6 \mathrm{cmH} 2 \mathrm{O})$ comparativamente aos indivíduos do grupo controlo $\left(P_{\text {imax }}=99,4 \mathrm{cmH}_{2} \mathrm{O}\right.$ e $\left.P_{\text {emax }}=121,8 \mathrm{cmH}_{2} \mathrm{O}\right)$.

Harraf et al. (2008) (24) avaliaram a força muscular respiratória em 15 indivíduos na fase aguda do AVC comparativamente a 16 indivíduos saudáveis pareados por idade e sexo. Os resultados demostraram uma diminuição significativa das pressões inspiratória e expiratória máximas em indivíduos do grupo $\operatorname{AVC}\left(P_{\mathrm{imax}}=\right.$ $36,7 \mathrm{cmH}_{2} \mathrm{O}$ e $P_{\text {emax }}=62,6 \mathrm{cmH}_{2} \mathrm{O}$ ) comparativamente ao grupo controlo $\left(P_{\text {imax }}=75,8 \mathrm{cmH}_{2} \mathrm{O}\right.$ e $P_{\text {emax }}=102,7$ $\mathrm{cmH}_{2} \mathrm{O}$ ).

Ward et al. (2010) ${ }^{(7)}$ também verificaram redução significativa $(p<0.05)$ dos valores de $P_{\text {imax }}\left(38,9 \mathrm{cmH}_{2} \mathrm{O}\right)$ e $P_{\text {emax }}\left(52,5 \mathrm{cmH}_{2} \mathrm{O}\right)$ em 18 adultos com AVC agudo 
ic stroke. The stroke group included 16 subjects with hemiparesis and an after-lesion mean time higher than 9 months, while the control group included 19 healthy subjects matched for age. Weakness of the inspiratory and expiratory muscles was observed among the stroke group, with $M I P$ and $M E P$ values $21 \%$ and $10 \%$ lower than predicted, respectively.

Pollock et al. (2012) ${ }^{(25)}$ conducted a systematic review to determine the levels of respiratory muscle weakness in patients with stroke. A meta-analysis of four of previously cited studies ${ }^{(5,24,7,8)}$ showed that the MIP was significantly lower in 57 registered stroke individuals compared with 64 control individuals (weighted average of $41.39 \mathrm{cmH}_{2} \mathrm{O}, 95 \%$ of confidence interval (CI) $29.03 \mathrm{cmH}_{2} \mathrm{O}$ to $\left.53.74 \mathrm{cmH}_{2} \mathrm{O}, p<0.00001\right)$, as well as $M E P$ (weighted average of $54.62 \mathrm{cmH}_{2} \mathrm{O}, 95 \% \mathrm{CI}$, $47.81 \mathrm{cmH}_{2} \mathrm{O}$ to $\left.61.24 \mathrm{cmH}_{2} \mathrm{O}, p<0.00001\right)$.

The reduction in respiratory muscle strength in individuals after stroke is a common and serious complication, and can lead to impaired lung function ${ }^{(21)}$, with changes in capacity and ventilatory volumes ${ }^{(8,16)}$.

According to Teixeira - Salmela et al. $(2005)^{(8)}$, changes in lung ventilation may occur after stroke due to reduction of the contribution of the abdominal compartment during the respiratory cycle. The Tomczak et al. study $(2008)^{(26)}$ demonstrated that, after stroke, those individuals presented reduced electromyographic activity of the paretic diaphragm muscle and lower values of forced vital capacity (FVC), $1^{\text {st }}$ second forced expiratory volume $(F E V 1)$ and tidal volume $(V t)$ when compared to predictive values.

Almeida et al. (2011) ${ }^{(16)}$ evaluated the effects of hemiplegia on pulmonary function in 20 patients with chronic stroke compared to 14 healthy subjects. Results have shown that individuals with stroke had significantly reduced values of peak expiratory flow (PEF), forced expiratory flow $25 \%-75 \%$ (FEF $25 \%$ - $75 \%$ ) and FEV1. The authors concluded that these changes could be attributed to expiratory muscle weakness, whereas $M E P$ values were significantly reduced in these patients, and in addition, they did not show any clinical or spirometric evidence of airflow obstruction, respiratory infections or lesions of the abdominal muscles.

The acute phase of stroke is associated with an increased risk of death due to respiratory factors, occurring largely from infections such as pneumonia. The probability of infection increases when aspiration of pulmonary secretions occurs through an inability to cough, or by weakness of the respiratory muscles, especially those in the abdomen ${ }^{(7,14,27)}$. However, McCool (2006) ${ }^{(28)}$ indicated cough may be impaired in individuals after stroke both by inspiratory muscle weakness, resulting in a low lung volume at the start of cough, comparativamente a 19 adultos saudáveis $P_{\text {imax }}(95,1$ $\left.\mathrm{cmH}_{2} \mathrm{O}\right) P_{\text {emax }}\left(108,7 \mathrm{cmH}_{2} \mathrm{O}\right)$.

$\mathrm{O}$ estudo de Teixeira-Salmela et al. (2005) (8) foi o primeiro a avaliar a $P_{\text {imax }}$ e a $P_{\text {emax }}$ em adultos com AVC crónico. O grupo AVC foi constituído por 16 indivíduos com hemiparesia e tempo médio de lesão superior a 9 meses e o grupo controlo por 19 indivíduos saudáveis pareados por idade. Nos resultados, foi observado fraqueza da musculatura inspiratória e expiratória nos indivíduos do grupo AVC, cujos valores de $P_{\text {imax }}$ e $P_{\text {emax }}$ estavam $21 \%$ e $10 \%$, respetivamente, abaixo dos valores previstos.

Pollock et al. (2012) ${ }^{(25)}$ realizaram uma revisão sistemática com o objetivo de determinar os níveis de fraqueza dos músculos respiratórios em pacientes com AVC. A meta-análise dos quatro estudos citados anteriormente ${ }^{(5,24,7,8)}$ revelou que a $P_{\text {imax }}$ foi significativamente menor nos 57 indivíduos registados com AVC em comparação aos 64 indivíduos registados no grupo controlo (média ponderada de 41,39 $\mathrm{cmH}_{2} \mathrm{O}, 95 \%$ de intervalo de confiança (IC), entre $29,03 \mathrm{cmH}_{2} \mathrm{O}$ e 53, 74 $\mathrm{cmH}_{2} \mathrm{O} ; p<0,00001$ ), assim como a $P_{\text {emax }}$ (média ponderada de $54,62 \mathrm{cmH}_{2} \mathrm{O}$, IC $95 \%$, entre $47,81 \mathrm{cmH}_{2} \mathrm{O}$ e $\left.61,24 \mathrm{cmH}_{2} \mathrm{O} ; p<0,00001\right)$.

A redução da força dos músculos respiratórios em indivíduos com AVC, em qualquer fase da doença, é uma complicação frequente e séria e pode levar a uma função ventilatória prejudicada ${ }^{(21)}$ com alteração das capacidades e volumes ventilatórios ${ }^{(8,16)}$.

De acordo com Teixeira-Salmela et al., $(2005){ }^{(8)}$, após o AVC, pode ocorrer alterações da ventilação pulmonar devido a redução da contribuição do compartimento abdominal durante o ciclo respiratório. O estudo de Tomczak et al., (2008) (26) demostrou que indivíduos após serem acometidos pelo AVC apresentaram diminuição da atividade eletromiográfica do músculo diafragmático do lado parético, bem como valores reduzidos de capacidade vital forçada $(\mathrm{CVF})$, volume expiratório máximo ao primeiro segundo (VEMS) e volume corrente comparativamente aos valores preditivos.

Almeida et al. (2011) ${ }^{(16)}$ avaliaram os efeitos da hemiplegia sobre a função pulmonar em 20 indivíduos com AVC crónico comparativamente a 14 indivíduos saudáveis. Os resultados demostraram que os indivíduos com AVC apresentaram valores significativamente reduzidos de débito expiratório máximo instantâneo (DEMI), débito expiratório máximo $25 \%$ - $75 \%$ (DEM $25 \%-75 \%$ ) e VEMS. Os autores concluíram que tais alterações podem ser atribuídas a fraqueza dos músculos expiratórios, visto que os valores de $P_{\text {emax }}$ estavam significativamente reduzidos nestes pacientes com AVC e, além disso, estes não apresentaram evidência clínica ou espirométrica de obstrução do fluxo aéreo, infeções respiratórias ou lesões dos músculos abdominais.

A fase aguda do AVC está associada a um elevado risco de morte devido à fatores respiratórios e grande parte ocorre como consequência de infecções pulmonares 
and by expiratory muscles weakness, leading to a reduction in the intrathoracic pressure needed to produce adequate airflow during cough.

In the chronic phase of the disease, individuals have greater fragility, low resistance during exercise ${ }^{(8)}$ and may have impaired respiratory function as a result of respiratory muscle weakness and postural dysfunction of the trunk ${ }^{(29)}$.

\section{Why do these changes occur?}

Cortical motor representation of the diaphragm and intercostal muscles is bilateral and, consequently, these muscles are little influenced by unilateral corticospinal lesions, as happens with stroke ${ }^{(6)}$. Therefore, it is believed that in patients affected by stroke, the respiratory muscle weakness can be directly related to the sequelae of the stroke.

Changes in postural motor control that can lead to impairment of the motor function and voluntary motor control required to maintain the synergy of the trunk muscles do occur as a result of hemiparesis or hemiplegia ${ }^{(13,14,30,31)}$. Respiratory function is also impaired, since the trunk muscles, in addition to being responsible for the stability and mobility of the trunk, also act in breathing control ${ }^{(5,13)}$. Pizzi et al. $(2001)^{(32)}$ indicated that the post-stroke respiratory muscle weakness may be directly related to the changes that occur in muscle tone and viscoelastic properties of the trunk muscles, causing spasm and stiffness in the thoracic cage, thus leading to loss of capacity and performance of respiratory muscle movement.

Teixeira - Salmela et al. (2005) ${ }^{(8)}$ described the occurrence of a decrease in abdominal muscle activation after the onset of stroke, and this modifies the thoracic cage positioning, which tends to remain in an inspiration position. In this framework, the respiratory muscles do not work efficiently, leading to a loss of respiratory function in patients with hemiparesis/hemiplegia. Furthermore, the reduction of the muscular respiratory force may also be related to the fact that stroked individuals are more inactive due to their physical conditions ${ }^{(6)}$.

\section{Respiratory Muscle Training}

Due to the impact of stroke on respiratory function, affected individuals are prone to serious respiratory complications. Recent studies emphasize the importance como a pneumonia. A probabilidade de infecção aumenta nos casos em que há broncoaspiração da secreção pulmonar devido à inabilidade em tossir, resultante da fraqueza dos músculos respiratórios, principalmente, dos abdominais ${ }^{(7,14,27)}$. Porém, para $\mathrm{McCool}(2006){ }^{(28)}$, em indivíduos com AVC, a tosse pode estar prejudicada tanto pela fraqueza dos músculos inspiratórios que resulta em um baixo volume pulmonar no início da tosse, como pela fraqueza dos músculos expiratórios que leva a redução da pressão intratorácica necessária para produzir o fluxo de ar adequado durante a tosse.

$\mathrm{Na}$ fase crónica da doença, os indivíduos apresentam maior fragilidade, baixa resistência durante o exercício (8) e podem ter função respiratória prejudicada como consequência da fraqueza muscular respiratória e da disfunção postural do tronco ${ }^{(29)}$.

\section{Porque é que essas alterações ocorrem?}

A representação cortical motora dos músculos diafragma e intercostais é bilateral e, sendo assim, estes músculos são pouco influenciados por lesões corticoespinais unilaterais, como é o caso do AVC ${ }^{(6)}$. Portanto, acredita-se que a fraqueza dos músculos respiratórios nos pacientes acometidos pelo AVC pode estar diretamente relacionada as sequelas da própria doença.

Como consequência da hemiplegia ou hemiparesia, ocorre alterações no controlo motor e postural que podem levar ao comprometimento da função motora voluntária e do controlo motor necessário para a manutenção da sinergia dos músculos do tronco ${ }^{(13,14,30,31)}$. A função respiratória também fica prejudicada, uma vez que os músculos do tronco também atuam no controlo da respiração, além de serem responsáveis pela estabilidade e mobilidade do tronco ${ }^{(5,13)}$.

Para Pizzi et al. (2001) ${ }^{(32)}$, a fraqueza dos músculos respiratórios após AVC pode estar diretamente relacionada as alterações que ocorrem no tónus muscular e nas propriedades viscoelásticas dos músculos do tronco, causando contratura e rigidez da caixa torácica e levando, assim, à perda da capacidade e desempenho dos movimentos dos músculos respiratórios.

Para Teixeira-Salmela et al., (2005) ${ }^{(8)}$, após a instalação do AVC, ocorre uma diminuição da ativação dos músculos abdominais, com consequente alteração no posicionamento da caixa torácica, que tende a permanecer em uma posição de inspiração. Neste quadro, os músculos respiratórios não funcionam eficientemente, levando a um prejuízo da função respiratória nos portadores de hemiparesia/plegia.

Além disso, a redução da força muscular respiratória pode estar relacionada também ao facto de os indivíduos com AVC serem mais inativos devido às suas condições físicas ${ }^{(6)}$.

\section{Treino Muscular Respiratório}

Devido as repercussões do AVC na função respiratória, os indivíduos acometidos pela doença estão propensos a apresentar sérias complicações respiratórias. Com o 
of respiratory muscle training in these patients ${ }^{(33)}$ to reduce the latter risks and improve respiratory muscle function.

In order to conduct training of the respiratory muscles, it is necessary to begin with an assessment of respiratory muscle strength with maximal respiratory pressures. Inspiratory muscles can be strengthened through a workout program with threshold load that provides increased strength and "endurance" of these muscles, improving their working condition and avoiding fatigue. The most common training method with load for the inspiratory muscles is the Threshold method originally described by Nickerson and Keens in 1982, in which a load and a plunger were used to induce the patient to generate and sustain an inspiratory pressure adequate to achieve a certain flux ${ }^{(34)}$. Currently, the Threshold IMT ${ }^{\circledR}$ is used. It is device which produces a resistance to inspiration by means of a spring system with a oneway valve and a nose clip. The more the spring is compressed, the greater the resistance, measured in $\mathrm{cmH}_{2} \mathrm{O}$ units ${ }^{(34)}$. This is a valuable small effective device that can easily be used in clinics, hospitals or even at home operated by the patient.

There is published evidence regarding the improvement of respiratory function, respiratory muscle strength, exercise capacity, quality of life and functional capacity in patients with Multiple Sclerosis ${ }^{(35,36)}$, Parkinson's disease ${ }^{(37)}$, and Myasthenia Gravis ${ }^{(38)}$ after having follow a program of inspiratory muscle training (IMT) with threshold load. These results suggest that IMT may be beneficial for individuals with neurological diseases.

As previously mentioned, studies have shown that individuals affected by stroke have decreased respiratory muscle strength. Based on these facts, two articles recently about the effects of a program of TMR in stroke patients have been published. Sutbeyaz et al. (2010) (6) studied the differences between inspiratory muscle training (IMT) and respiratory exercises (RE) in 45 individuals after the first stroke episode and with an injury time of less than 12 months. Patients were divided into three groups - TMI group, RE group, and control group and each included 15 individuals. Patients with cardiac or respiratory disease, or cognitive changes of consciousness were excluded. All individuals, including the control group, were assessed for lung function, respiratory muscle strength, functional capacity by the Barthel Index, and quality of life. The IMT group patients were trained with the Threshold IMT ${ }^{\circledR}$ device, with an initial load of $40 \%$ of the initial MIP. The load was gradually increased from $5 \%$ to $10 \%$ per day until it reached the value of $60 \%$ of the MIP. The RE group performed 15 minutes of diaphragmatic breathing combined with pursed-lip breathing (PLB), followed by 5 objetivo de reduzir esses riscos e melhorar a função dos músculos respiratórios, estudos recentes enfatizam na importância do treino da musculatura respiratória nestes pacientes ${ }^{(33)}$.

Para a realização de treino da musculatura respiratória, é necessário, primeiramente, que seja avaliada a força dos músculos respiratórios através das pressões respiratórias máximas. Os músculos inspiratórios, podem ser fortalecidos através de um programa de treino com carga limiar que proporciona um aumento da força e da "endurance" desses músculos, melhorando suas condições de trabalho e evitando o surgimento de fadiga. O método mais comum para treino com carga dos músculos inspiratórios é o Threshold descrito primeiramente por Nickerson e Keens, em 1982, no qual se utilizava uma carga e um embolo em que o indivíduo deveria gerar e sustentar uma pressão inspiratória, a fim de alcançar determinado fluxo ${ }^{(34)}$

Atualmente, utiliza-se o Threshold IMT ${ }^{\circledR}$ que é um aparelho que produz uma resistência ao inspirar, por meio de um sistema de mola com uma válvula unidirecional e utilização de clipe nasal. Quanto mais a mola estiver comprimida, maior será a resistência, que tem como unidade de medida $\mathrm{cmH} 2 \mathrm{O}{ }^{(34)}$. Trata-se de um dispositivo vantajoso, pequeno, eficaz e que pode ser utilizado com facilidade em clínicas, hospitais ou até mesmo em casa pelo próprio paciente.

$\mathrm{Na}$ literatura científica já existem evidências sobre a melhora da função respiratória, da força dos músculos respiratórios, capacidade de exercício, qualidade de vida e capacidade funcional em pacientes com Esclerose Múltipla ${ }^{(35,36)}$; Doença de Parkinson ${ }^{(37)}$ e Miastenia Gravis ${ }^{(38)}$ submetidos ao um programa de treino muscular inspiratório com carga limiar. Tais resultados sugerem que esse tipo de treino pode ser benéfico em indivíduos com doenças neurológicas.

Como citado anteriormente, estudos têm demostrado que indivíduos acometidos pelo AVC apresentam uma diminuição da força dos músculos respiratórios. Baseado neste facto, recentemente foram publicados dois artigos sobre os efeitos de um programa de treino muscular respiratório em pacientes com AVC.

Sutbeyaz et al. (2010) (6) estudaram as diferenças entre treino muscular inspiratório (TMI) e exercícios de cinesioterapia respiratória (CR) em 45 indivíduos no primeiro episódio de AVC e com tempo de lesão menor que 12 meses. Os pacientes foram divididos em três grupos: grupo TMI, grupo CR, grupo controlo e cada um foi constituído por 15 indivíduos. Pacientes com doença cardíaca ou respiratória, alterações de consciência ou cognitiva foram excluídos. Todos os indivíduos, inclusive do grupo controlo foram submetidos a avaliações da função pulmonar, força muscular respiratória, capacidade funcional pelo Índice de Barthel, e quali- 
minutes of fractionated inspiration and 10 minutes of maximal inspiration sustained exercise. TMI and RE groups worked out 30 minutes every day, six times per week for 6 weeks. The primary results have shown that IMT group individuals had significantly $(p<0.01)$ higher FEV1, FEF $25 \%$ - $75 \%, F V C$, vital capacity $(\mathrm{VC})$ and maximal voluntary ventilation (MVV) when compared to the RE and control groups. The $P E F$ was significantly higher $(p<0.01)$ in the RE group compared to the other two groups. There was a significant increase $(p<0.01)$ of MIP and MEP in the RE group and MIP in IMT group compared to the control group and to the predicted values. Regarding the functional capacity, a significant increase in Barthel Index scores was found in IMT patients group. This study demonstrated positive effects of the inspiratory muscular training program in regard to the respiratory muscle function, exercise capacity, and functional capacity of stroke patients.

Britto et al. (2011) ${ }^{(33)}$ studied the effects of IMT in 9 individuals with chronic stroke (lesion time higher than 9 months) compared to 9 healthy individuals matched for sex and age. Patients with cardiac, respiratory, facial paralysis and other neurological diseases history were excluded. All subjects underwent assessment of respiratory muscle strength and quality of life. The stroke group applied the Threshold IMT ${ }^{\circledR}$ respiratory training with a load of $30 \%$ of the initial MIP while the resistance was weekly adjusted according to the new MIP value of. The same training protocol was applied to the control group but without the resistance valve procedure. Both groups applied the IMT at home once a day, with a 30-minute session, five times a week for eight weeks. After the IMT program, MIP and MEP values were significantly increased in the stroke group compared to the control group. The authors concluded that the IMR program significantly impacted, in the shortterm, the inspiratory muscle strength in chronic hemiplegic patients.

The clinical trials here described were heterogeneous regarding injury time, inclusion criteria and number of evaluated patients. The protocol used for training of the respiratory muscles, the duration of sessions, the number of repetitions in each series, the initial load used, and the total duration of the workout also differed. Although these trials differ in methodology, all point to the significant therapeutic potential involved with inspiratory muscle training for rehabilitation of individuals with stroke, improvement in respiratory muscle function, cardiorespiratory fitness, and quality of life. Xiao et al. (2012) ${ }^{(39)}$ recently conducted a systematic review on the inspiratory muscle training in patients with stroke involving two articles mentioned above. dade de vida. Os pacientes do grupo TMI realizaram treino utilizando o dispositivo Threshold IMT®, com carga inicial de $40 \%$ do valor de $P_{\text {imax }}$ inicial e gradualmente a carga era aumentada entre $5 \%$ a $10 \%$ por dia até atingir o valor de $60 \%$ da $P_{\text {imax }}$. O grupo CR realizava 15 minutos de respiração diafragmática combinada com freno labial, seguido de 5 minutos de inspiração fracionada e 10 minutos de exercícios de inspiração sustentada. Os grupos TMI e CR realizavam por dia um treino de 30 minutos, seis vezes por semana durante 6 semanas. Os principais resultados demostraram que os indivíduos do grupo TMI tiveram aumento significativo $(p<0,01)$ na $V E M S, D E M 25 \%-75 \%, C V F$, capacidade vital $(C V)$ e ventilação máxima voluntária (VMV) comparativamente ao grupo $\mathrm{CR}$ e controlo. $\mathrm{O}$ $D E M I$ foi significativamente maior $(p<0,01)$ no grupo CR comparativamente aos outros dois grupos. Houve um aumento significativo $(p<0,01)$ da $P_{\text {imax }}$ e $P_{\text {emax }}$ no grupo CR e da $P_{\text {imax }}$ no grupo TMI em comparação ao grupo controlo e aos valores preditos. Em relação à capacidade funcional, houve um aumento significativo da pontuação do Indice de Barthel, nos pacientes do grupo TMI. Foi observado neste estudo efeitos positivos do programa de treino muscular inspiratório em relação a função muscular respiratória, capacidade de exercício e capacidade funcional de pacientes com AVC.

Britto et al. (2011) ${ }^{(33)}$ estudaram os efeitos do TMI em 9 indivíduos com AVC crónico (tempo de lesão superior a 9 meses) comparativamente a 9 indivíduos saudáveis pareados por sexo e idade. Pacientes com doença cardíaca, respiratória, paralisia facial e histórico de outras doenças neurológicas foram excluídos. Todos os sujeitos foram submetidos a avaliação da força muscular respiratória e qualidade de vida. O Grupo AVC realizou o treino respiratório através Threshold IMT®, com carga de $30 \%$ da $P_{\text {imax }}$ inicial, a resistência era ajustada semanalmente conforme o novo valor de $P_{\text {imax }}$, o grupo controlo foi submetido ao mesmo protocolo de treino do grupo AVC, porém sem a válvula de limite de resistência. Ambos os grupos realizaram o TMI em casa, uma vez por dia com duração de 30 minutos a sessão, cinco vezes por semana e durante oito semanas. Após o programa de TMI, foi observado aumento significativo dos valores de $P_{\text {imax }}$ e $P_{\text {emax }}$ no Grupo AVC comparativamente ao grupo controlo. Os autores concluíram que houve efeitos significativos a curto prazo do programa de TMI em relação à força muscular inspiratória em pacientes hemiplégicos crónicos.

Os ensaios clínicos descritos acima apresentaram heterogeneidade da amostra, quanto ao tempo de lesão, critérios de seleção e número de pacientes avaliados. Existe diferença também quanto ao protocolo utilizado para treino da musculatura respiratória, quanto à duração das sessões, número de repetições de cada série, a carga inicial utilizada e a duração total do treino.

Embora existam diferenças nas metodologias utilizadas em cada estudo, estes apontam que o treino da mus- 
According to these authors, the recognized methodological limitations allow them to affirm that there is not sufficient evidence thus far to classify IMT as an effective and safe method in the improvement of respiratory muscle function in stroke patients. Future research with controlled, randomized, double- blind clinical trials, applied to wider samples, is needed to evaluate the efficacy and safety of respiratory muscle training and its effects on functional capacity and quality of life in stroke patients.

\section{Conclusions}

All of the publications analyzed here have shown that there is evidence that patients affected by stroke, acute and chronic, may have decreased inspiratory and expiratory muscle strength which may impair lung function and cough capacity. Recent studies suggest that the inclusion of respiratory muscle training might benefit stroke patients by improving respiratory function and respiratory muscle strength, particularly in patients with no history of lung and heart disease or in the absence of respiratory decompensation signs. However, results are still limited. Future studies should be conducted to deepen the knowledge of the benefits, long term effects and potential negative effects of respiratory rehabilitation in stroke affected patients.

\section{Conflict of Interests}

The authors declare that there are no financial and personal relationships that could be viewed as a potential conflict of interests. culatura inspiratória têm um grande potencial terapêutico para reabilitação de indivíduos com AVC, quanto à melhora da função dos músculos respiratórios, aptidão cardiorrespiratória e qualidade de vida.

Porém, Xiao et al. (2012) ${ }^{(39)}$ realizaram recentemente uma revisão sistemática sobre o treino muscular inspiratório em pacientes com AVC, no qual foram avaliaram dois artigos citados anteriormente. Segundo os autores, ambos estudos apresentaram limitações metodológicas e, até o presente momento, não há evidências suficientes para apoiar o uso de TMI como método eficaz e seguro na melhora da função dos músculos respiratórios em pacientes acometidos pelo AVC. Investigações futuras com ensaios clínicos controlados, randomizados, duplo cego e com amostras maiores são necessárias para a avaliar a eficácia e segurança do treino muscular respiratório e seus efeitos sobre a capacidade funcional e qualidade de vida dos pacientes com AVC.

\section{Conclusões}

Os artigos científicos analisados neste estudo demostraram que existem evidências de que pacientes acometidos pelo AVC, tanto na fase aguda como crónica, podem apresentar diminuição da força muscular inspiratória e expiratória e como consequência desta apresentar piora da função pulmonar e inabilidade de tossir.

Estudos recentes sugerem que a inclusão de treino muscular respiratório pode trazer benefícios quanto à melhora da função respiratória e da força dos músculos respiratórios em pacientes com AVC sem histórico de doença pulmonar e cardíaca prévia e sem sinais de descompensação respiratória. Porém, os resultados ainda são escassos. Estudos futuros devem ser realizados para o aprofundamento do conhecimento sobre os benefícios, efeitos a longo prazo e também possíveis efeitos negativos da reabilitação respiratória em pacientes com AVC.

\section{Conflito de interesses}

Os autores declaram não existir qualquer relação de natureza financeira ou pessoal que possa, ser entendida como, ou representar, um potencial conflito de interesses. 


\section{References/ Referências}

1.European Stroke Organization (ESO). Guidelines for management of ischemic stroke and transient ischemic attack. Cerebrovascular Diseases 2008; 25(5):457-507.

2.Wolfe CD \& Rudd T. The Burden of Stroke White Paper. Stroke Alliance for Europe (SAFE), (2007). IN http://www.safestroke. org/Portals/10/FINAL\%20Burden $\% 20$ of $\% 20$ Stroke.pdf

3. Thorvaldsen P, Asplund K, Kuulasmaa K, Rajakangas AM, Schroll M. Stroke Incidence, Case Fatality, and Mortality in the WHO MONICA Project. Stroke 1995; 26: 361-367.

4. Andrews AW \& Bohannon RW. Distribution of muscle strength impairments following stroke. Clin Rehabil 2000; 14:79-87.

5. Lanini B, Bianchi R, Romagnoli I, Coli C. Chest wall kinematics in patients with hemiplegia. Am J Respir Crit Care Med 2003; 168: 109-113.

6. Sutbeyaz ST, Koseoglu F, Inan L, Coskun O. Respiratory muscle training improves cardiopulmonary function and exercise tolerance in subjects with subacute stroke: a randomized controlled trial. Clinical Rehabilitation 2010; 24: 240-250.

7. Ward K, Seymour, J, Steier J, Jolley CJ, Polkey MI, Kalra L, et al. Acute ischaemic hemispheric stroke is associated with impairment of reflex in addition to voluntary cough. Eur Respir J 2010; 36: 1383-1390.

8. Teixeira-Salmela LF, Parreira VF, Britto RR, Brant TS. Respiratory pressures and thoracoabdominal motion in communith-dwelling chronic stroke survivors. Arch Phys Med Rehabil 2005; 86: 1974-1978.

9. Green M, Road J, Sieck GC, Similowski T. Tests of respiratory Muscle Strength. In: American Thoracic Society/European Respiratory Society - ATS/ERS Statement on Respiratory Muscle Testing (2002). Am J Resp Crit Care Med 2002; 166: 528-542.

10. Syabbalo N. Assessment of respiratory muscle function and strength. Postgrad Med J 1998; 74: 208-215.

11. Polkey MI, Green M, Moxham J. Measurement of respiratory muscle strength. Thorax 1995; 50: 1131-1135.

12. Similowski T, Catala M, Rancurel G, Derenne JP. Impairment of central motor conduction to the diaphragm in stroke. American Journal of Respirtory and Critical Care Medicine 1996; 154 (2): 436-41.

13. Howard RS, Rudd AG, Wolfe CD, Williams A J. Pathophysiological and cli $\neg$ nical aspects of breathing after stroke. Postgrad Med J 2001; 77: 700-2.

14. Polkey MI, Lyall RA, Moxham J, Leigh PN. Respiratory aspects of neurological disease. J. Neurol Neurosurg Phychiatry 1999; 66: 05-15.
15. Vingerhoets F \& Bogousslavsky J. Respiratory dysfunction in stroke. Clinics in Chest Medicine 1994; 15 (4): 729-736.

16. Almeida ICL, Clementino ACR, Rocha EHT, Brandão DC, Andrade AD. Effects of hemiplegy on pulmonary function and diaphragmatic dome displacement. Respiratory Phisiology \& Neurobiology 2011; 178: 196201.

17. Jandt SR, Caballero RMS, Júnior LAF, Dias AS. Correlation between Trunk Control Respiratory Muscle Strength and Spirometry in Patients with Stroke: An Observational Study. Physiother. Res. Int 2011; 16: 218-224.

18. Roth EJ, Noll SF. Stroke rehabilitation. 2. Comorbidities and complications. Arch Phys Med Rehabil 1994; 75: S42-S46.

19. Korczyn AD, Hermann G \& Don R. Diaphragmatic involvement in hemiplegia and hemiparesis. J. Neurol. Neurosurg. Psychiat 1969; 32: 588-590.

20. De Troyer A, De Beyl DZ \& Thirion M. Function of respiratory muscles in acute hemiplegia. Am Rev Respir Dis 1981; 123 : 631-2.

21. Khedr EM, El Shinawy O, Khedr T, Aziz Ali YA, Awad EM. Assessment of corticodiaphragmatic pathway and pulmonary function in acute ischemicstroke patients. Eur J Neural 2000, 7 (3): 323- 30.

22. Harik-Khan RI, Wise RA, \& Fozard J. Determinants of Maximal Inspiratory Pressure The Baltimore Longitudinal Study of Aging. Am J Respir Crit Care Med 1998; 158: 1459-1464.

23. Neder JA, Andreoni S, Lerario MC, Nery LE.. Reference values for lung function test. II. Maximal respiratory pressures and voluntary ventilation. Brazilian Journal of Medical and Biological Research 1999; 32:719727.

24. Harraf F, Ward K, Man W, Rafferty G, Mills K, Polkey M., et al. Transcranial magnetic stimulation study of expiratory muscle weakness in acute ischemic stroke. Neurology 2008; 71: 2000- 2007.

25. Pollock RD, Rafferty GF, Moxham J, Kalra L. Respiratory muscle strength and training in stroke and neurology: a systematic review. International Journal of Stroke 2012; 2: $1-5$.

26. Tomczak CR, Jelani A, Haennel RG, Haykowsky MJ, Welsh R, et al. Cardiac reserve and pulmonary gas exchange kinetics in patients with stroke. Stroke 2008; 39: 3102-06.

27. Castillo PR \& Reinoso MA. Respiratory Dysfunction associated with acute cerebrovascular events. Revista Equatoriana de Neurologia 1999; 8 (1-2): 134-140.
28. McCool FD. Global physiology and pathophysiology of cough. Chest 2006, 129: 4853.

29. Annoni JM, Ackermann, D \& Kesselring J. Respiratory function in chronic hemiplegia. Int. Disabil. Studies 1990; 12: 78-80.

30. McKay LC, Evans KC, Frackowiak RSJ \& Corfield, DR. Neural correlates of voluntary breathing in humans. J. Appl. Physiol 2003; 95: 1170-1178.

31. Nelles G, Spiekermann G, Jueptner M, Leonhardt G, Muller S, Gerhard H, et al. Reorganization of sensory and motor systems in hemiplegic stroke patients: a positron emission tomography study. Stroke 1999; 30: 1510-6.

32. Pizzi A, Carlucci G, Falsini C, Verdesca S, Grippo A. Application of a volar static splint in poststroke spasticity of the upper limb. Archives of Physical Medicine and Rehabilitation 2005; 80 (9): 1855-1859.

33. Britto RR, Rezende NR, Marinho KC, Torres JL, Parreira VF, Teixeira-Salmela, LF. Inspiratory muscular training in chronic stroke survivors: a randomized controlled trial. Arch Phys Med Rehabil 2011; 92(2):184-90.

34. Johnson PH, Cowley AJ, Kinnear WJM. Evaluation of the threshold trainer for inspiratory muscle endurance training comparison with the weighted plunger method. Eur Respir J 1996; 9: 2681-2684.

35. Fry DK, Pfalzer LA, Chokshi AR, Wagner M.T, Jackson ES. Randomized control trial of effects of a 10 week inspiratory muscle training programon measures of pulmonary function in persons with multiple sclerosis. J Neurol Phys Ther 2007; 31:162-72.

36. Smeltzer SC, Levietes MH \& Cook SD. Expiratory training in multiple sclerosis. Arch Phys Med Rehabil 1996, 77:909-12.

37. Inzelberg R, Peleg N, Nisipeanu P, Magdle $\mathrm{R}$, Carasso R L, Weiner P. Inspiratory muscle training and the perception of dyspnea in Parkinson's disease. Can J Neurol Sci 2005; 32:213-7.

38. Fregonezi GA, Resqueti VR, Guell R, Pradas J, Casan P. Effects of 8-week, intervalbased inspira- tory muscle training and breathingretraining in patients with generalized myasthenia gravis. Chest 2005; 128 : 1524-30.

39. Xiao Y, Luo M, Wang J, Luo H. Inspiratory muscle training for the recovery of function after stroke (review). Cochrane Database Syst Rev 2012, 5: 1-27. 